\title{
OBITUARY
}

\section{VLADIMIR FEDOROVICH MINORSKY}

The passing on 25 March 1966 of Professor Emeritus Vladimir Fedorovich Minorsky, at the age of 89 , takes from our midst a scholar of international eminence who combined immense learning with a rare capacity to befriend and encourage younger workers of all nationalities, and to inspire personal affection and loyalty among all those who knew him.

Vladimir Minorsky was born on 6 February 1877 at the small town of Korcheva on the Upper Volga, now submerged beneath the waters of the Moscow Sea. His parents were Fedor M. Minorsky and his wife Olga, née Golubitsky. He went to school in Moscow, and was a gold medallist of the Fourth Grammar School in the graduation of 1896. Minorsky then read law at Moscow University. With a view to embarking on a diplomatic career in the East, he entered in 1900 the Lazarev Institute of Oriental Languages, which occupied that same picturesque old building in the Armyansky Pereulok in central Moscow which now houses the Institute of Peoples of Asia of the Soviet Academy of Sciences.

During his stay at the Institute, from 1900 to 1903, Minorsky studied Persian under Professor F. E. Korsh, Mīrzā Ja'far Mahallātī, Mīrzā 'Abdullāh Ghaffarov, and Baron R. Stackelberg; Arabic under Professor A. E. Krymsky and Mr. Mīkhā'il 'Ațāyā; Turkish under Dr. Stavros Sakov and Mr. S. Dzerunian; and Near Eastern history under Professor Vsevolod F. Miller. He also acquired a competent knowledge of English, later to stand him in such good stead. As a second year student, Minorsky paid his first visit to Iran in the summer of 1902. During this trip, partly under the stimulus of the writings of Professor E. G. Browne, he began to collect material on the esoteric sect of the Ahl-i Hiaqq, or People of Truth, sometimes known as 'Ali-Ilähi. This sect was the subject of his first substantial scholarly monograph, published in 1911 as fasc. 33 of the Works of the Lazarev Institute, and awarded the gold medal of the Ethnography Section of the Hoscow Imperial Society of Natural Sciences.

Meanwhile, in 1903, Vladimir Minorsky had entered the Imperial Russian Ministry of Foreign Affairs. Between 1904 and 1908, he served at the Russian Consulate-General in Tabriz and the Legation in Tehran, travelling extensively in Kurdistan and other regions of north-western Iran. It was in Tabriz that he later met his lifelong friend, the Persian statesman and scholar S. H. Taqizadeh, with whom he collaborated in publishing a short novel of Leo Tolstoy in Persian translation. This was a critical period in the history of modern Iran, embracing the Constitutional movement of 1905-6, and the subsequent partition of the country under the terms of the Anglo-Russian agreement of 1907. Russia's attempts to suppress the Persian Constitutional movement and turn much of the country into a province of the Tsarist empire were uncongenial to Minorsky, who did all that he properly could to dissociate himself from them. It is interesting to note that E. G. Browne, in a protest published in the British press, 


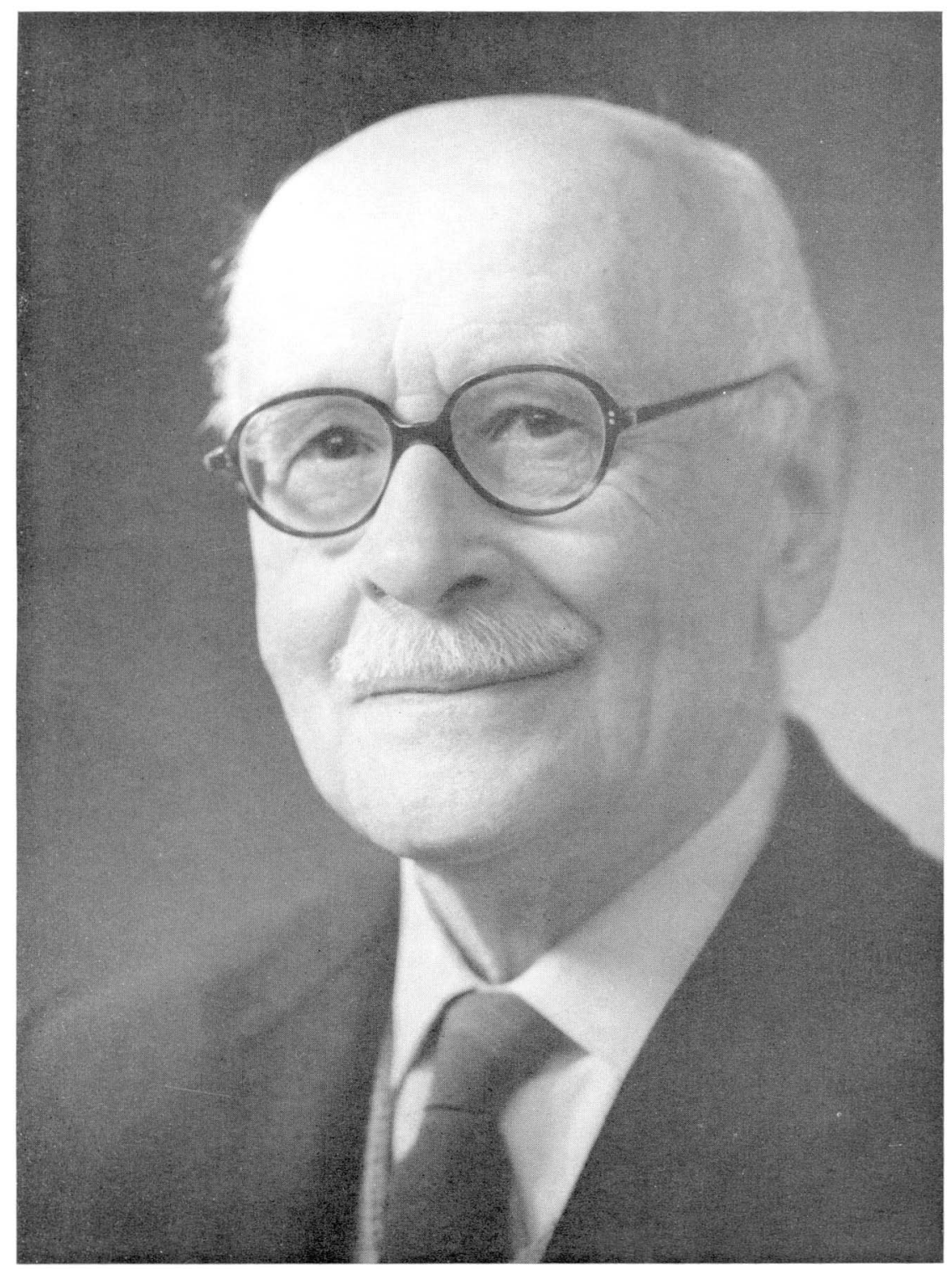

Vladimir Fedorovich Minorsky

BSOAS. NXIX] 
mentioned several Russian diplomats by name, including Minorsky ; but when Browne learnt Minorsky's real attitude to the Persian question, he publicly exonerated him, and Minorsky even stayed with Browne at his house in Cambridge. The Persians' particular regard for Minorsky, and also his association with the University of Cambridge, dated from that time.

In due course Minorsky was transferred, and recalled to the Foreign Ministry in St. Petersburg, where he made friends with several leading representatives of the Oriental section of the Academy of Sciences, notably V. V. Barthold, whose disciple he was always proud to consider himself. A year in Russian Turkistan as diplomatic attaché to the Governor-General, General Samsonov, gave him the chance to study at first hand the homeland of Tamerlane and Ulugh-Beg.

An important phase in Minorsky's public career began in 1911, when he was again dispatched to Iran, this time to collaborate with the British consul in Tabriz, Mr. Shipley, in surveying the terrain of Azerbaijan and Kurdistan prior to the setting up of a mixed boundary commission to settle the long-disputed frontier between Iran and the Ottoman Empire. There had never been a properly settled frontier between these two states, each one encroaching upon the other according to which happened to be stronger at any given time. There were also several autonomous sheikhdoms straddling the boundary area, the rulers of which habitually changed their allegiance to accord with the dictates of expediency. Consequently, there was a wide strip of disputed territory, extending virtually from Mount Ararat to the Persian Gulf. During the nineteenth century, Britain and Russia had several times urged the parties concerned to join with them in setting up a mixed commission to settle the matter ; the last important one had functioned from 1848 to 1852 , but was prevented from completing its task by the Crimean War. Minorsky's expert knowledge of the territory and the peoples and tribes involved fitted him ideally to represent Russia in this new attempt to fix the boundary. Following the exploration of north-western Iran by Minorsky and Shipley, the Commission's work was transferred to Istanbul, Minorsky proceeding there in 1912 with the rank of Second Secretary of the Russian Embassy to participate in four-power discussions and the preparation of the necessary maps and surveys.

A turning-point in Minorsky's life occurred in 1913, for it was then that he married Tatiana, née Shchebunin, his constant companion and inspiration for 52 years, and the charming and patient hostess so well beloved by scholars and celebrities who in later years came from all over the world to pay their respect to the veteran teacher in his modest Cambridge home. The Minorskys' early married life was spent in the picturesque but rugged surroundings of the Turco-Persian border zone, to which Minorsky was detailed for the final stages of the boundary delimitation. Assembling at Muhammerah (Khurramshahr) in the Persian Gulf, the four-power commission set off northwards in February 1914. Each commission had its own doctor, several survey officers, and an armed escort (the Minorskys had ten cossacks), with a caravan of up to 120 mules. The party travelled on horseback. Work was brought to a successful 
end in October 1914, just as Turkey was entering World War I. The 'Minorsky frontier', which now separates Persia from both Iraq and Turkey, has stood the test of time for over 50 years.

In the course of this work, Minorsky acquired further knowledge of the dialects and ethnography of the region. The results of his topographical researches appeared in the second volume of the 'Materials for the study of the East', published in 1915 by the Russian Ministry of Foreign Affairs, and also featured in the Proceedings of the Imperial Russian Geographical Society for 1916. Thirty years later, in 1944, Minorsky was able to draw still further on his observations for an article on Roman and Byzantine campaigns in Atropatene, the modern Azerbaijan.

Following this arduous mission, Vladimir Fedorovich returned to the Russian Legation in Tehran, this time as First Secretary (1916), and later as Chargé d'Affaires (1917). From this period dates his important epigraphical and archaeological study of the steles of Kelashin and Topuzava, and other ancient remains in the vicinity of Lake Urmia, published in 1917 in vol. 24 of the Bulletin of the Oriental Section of the Imperial Archaeological Society of Petrograd.

The Russian Revolution of 1917 placed Mr. and Mrs. Minorsky in an acute dilemma. To return to Soviet Russia at that time was impossible. In 1919, they proceeded to the Russian Embassy in Paris, where Minorsky hoped, in vain as it happened, to make himself useful by his expert knowledge to the Russian representatives at the drawing up of the Versailles Treaty. As a specialist on the modern Near East and Transcaucasia, Minorsky's pen was in demand among editors of journals devoted to politics and current affairs. He contributed to these a number of perceptive articles on contemporary Russia, Turkey, Azerbaijan, and Georgia, and also on Mosul, the international oil question, and modern Afghanistan. He was sceptical of the nationalist pretensions of the independent republics of Armenia, Azerbaijan, and Georgia, which in any case were soon swallowed up by the new might of Soviet Russia. He also wrote a valuable study of the death of another distinguished Russian diplomat, the dramatist Alexander Griboedov, murdered by a Tehran mob in 1829 .

In 1923, Vladimir Fedorovich had begun to teach Persian literature at the École Nationale des Langues Orientales Vivantes in the Rue de Lille, and later lectured on Turkish and Islamic history at that same institution. From 1925 onwards he was a regular contributor to the first edition of the Encyclopaedia of Islam, for which he wrote 110 articles, several of these being important monographs. His close connexion with England began in 1930, when he was appointed Oriental Secretary to the Persian Art Exhibition held at Burlington House in London, under the auspices of Riz̄a Shāh Pahlavi. He took an active part in preparing the catalogue of the exhibition, as well as delivering lectures on Persian illuminated manuscripts, Luristan bronzes, and the mosque of Veramin, which were subsequently published in the magazine Apollo.

Minorsky's work had already attracted the attention of that shrewd judge of men, the late Sir Denison Ross, Director of our School of Oriental Studies here 
in London. Sir Denison succeeded in luring Mr. and Mrs. Minorsky from Paris to the University of London, to which Minorsky devoted the remainder of his teaching career, first as Lecturer in Persian (1932), then as Reader in Persian Literature and History (1933), and finally, after Sir Denison's retirement in 1937, as Professor of Persian. When the School was evacuated to Cambridge in 1939, Professor and Mrs. Minorsky took up residence, first in Green Street, and then in Bateman Street, where Vladimir Fedorovich remained for the rest of his life. On reaching the age of 67 in 1944, Professor Minorsky retired, being appointed an Honorary Fellow of the School.

It was during his long and happy residence in England that Professor Minorsky attained the plenitude of his remarkable powers. From 1932 onwards, he was a regular reviewer and contributor to the Bulletin of the School, as well as to the Journal of the Royal Asiatic Society. Many of these articles were later collected and reprinted in Tehran in 1964-Iranica: twenty articles (Publications of the University of Tehran, Vol. 775) ; this volume also contains the most complete list of Professor Minorsky's books, articles, and reviews, amounting to 206 separate items or groups of writings, and also a curriculum vitae.

Professor Minorsky's magnum opus appeared in the Gibb Memorial Series in 1937-a critical translation of the anonymous Persian geography entitled Hudüd al-'alam, or 'The regions of the world', written in 372/982; the translation contained 12 maps, together with an English translation of V. V. Barthold's original Russian preface. This indispensable work attracted attention throughout Europe, America, and the Soviet Union, and was followed up in 1942 by an edition and translation of Sharaf al-Zamān Țāhir Marvazì, $O n$ China, the Turks and India, published by the James G. Forlong Fund of the Royal Asiatic Society. Here and there, Minorsky's Arabic could occasionally be faulted by the pundits, but in view of his vast output, this was perhaps unavoidable. As Dr. J. A. Boyle remarks, ' the field of his historical and geographical investigations embraced the whole of Eurasia from the Balkans to China with special emphasis on the Caucasus area and, above all, Central Asia. His translations of and commentaries on two geographical texts of the tenth and eleventh centuries respectively are works of extraordinary erudition, and throw much new light on the early history of the various Turkish peoples before their conversion to Islam'. Another standard work of this period wash is facsimile edition and translation and commentary on the Tadhkirat al-mulukk, a manual of Safavid administration and finance composed around 1725, during the Afghan occupation of Persia.

Seldom can a scholar have had so long and busy a retirement as Professor Minorsky. Between 1944 and his death, with Mrs. Minorsky's skilled and devoted collaboration, he produced no less than 11 volumes, several of them substantial, of original researches and translations, and about 100 articles and reviews, including many contributions to the second edition of the Encyclopaedia of Islam. His range of interest remained as wide as ever, covering the history, geography, literature, and fine arts of Persia, the early history of Caucasia, 
including Daghestan, Shirvan, Georgia, and Armenia, archaeology and numismatics, as well as Turkish and Central Asian studies. During World War II, the heroic struggle of the Russian people against the Nazis reawakened in Professor and Mrs. Minorsky their warm affection for their homeland, and helped them to re-establish contact with scientific circles in the Soviet Union, where they were welcomed with enthusiasm and deep respect when they visited Moscow, Baku, Erevan, and Tbilisi as guests of honour of the Soviet Academy of Sciences in connexion with the twentieth International Congress of Orientalists in 1960. During the academic year 1948-9, Vladimir Fedorovich was Visiting Professor at the Fuad University in Cairo, which in 1955 sponsored his publication, with English translation and commentary, of the tenth-century Arabic poet and traveller Abū Dulaf's journeys in Iran.

Many honours fell to Professor Minorsky's lot in the course of his career. He was elected Corresponding Fellow of the British Academy in 1943, and was an honorary member of the Société Asiatique, the Deutsche Morgenländische Gesellschaft and the Peruvian Institute for Islamic Studies. His seventy-fifth birthday was marked by the presentation of a volume of essays specially written by his friends and pupils, and published by the School of Oriental and African Studies as an issue of the Bulletin. In 1962 he was awarded the Royal Asiatic Society's triennial Gold Medal, on which occasion he made a characteristically modest and touching speech of thanks which will long be remembered by those present. He was elected in 1963 an Associate Member of the Académie des Inscriptions et Belles-Lettres. The University of Brussels conferred an honorary doctorate on him in 1948, to be followed 15 years later by the University of Cambridge.

Few eminent scholars have combined such immense erudition with such simplicity, sincerity, and absence of conceit. One of his contemporaries. Professor A. S. Tritton, recently remarked to me: 'The great thing about Minorsky was that he had no " side" '. Not for him the off-hand air, the proconsular manner with which some bolster up their academic weight. He enjoyed parties and academic gatherings, and was much in demand socially. To the end of his days, he was eager to appreciate and encourage the potential talents and apprentice efforts of the humblest beginners. However busy, however tired, he was always genuinely pleased to see visitors young or old, and to give freely of his wisdom and knowledge. He was completely free from professional jealousy and egoism. I well remember how, when myself a tiro in the study of Caucasian numismatics, I used to receive from Professor Minorsky cuttings from the Soviet press, in which were announced important finds of ancient coins-data unobtainable elsewhere. Again, we may instance his sponsorship of Boyle's magistral translation of Juwaini's History of the world-conqueror, which Professor Minorsky helped to get accepted into the UNESCO series of representative works, and published in a splendid edition by the Manchester University Press.

In his speech of thanks at the Royal Asiatic Society in 1962, Professor Minorsky said : ' I remember my joy when at every stage of my research I had 
the support and advice of a pleiad of excellent authorities in different fields of Oriental studies '. If Nöldeke, Barthold, Qazvini, Pelliot, and the others whom Vladimir Fedorovich named as his teachers were alive to-day, they would be proud to see the number and quality of the disciples whom Minorsky brought up in the great tradition which they had handed down. Death, the one fact which all scholars must accept, has taken away our teacher and friend in the fullness of years, but not before he had achieved and dispensed great learning, and set an inspiring example. We shall not see his like again.

D. M. LANG 